\title{
Perencanaan Proyek Pembangunan Office Centre Anfen Jalan Pringgading - Semarang
}

\author{
Andre; Stefen Sambuhak; \\ David Widianto dan Widija Suseno \\ e-mail: andrepimnohit88@gmail.com \\ Program Studi Teknik Sipil, Fakultas Teknik \\ Universitas Katolik Soegijapranata, Semarang
}

\begin{abstract}
AnFen Office Center building is used for office rentals, expected to be a place of business opportunity. The AnFen Office Center building includes office buildings that are used for professional business, administrative or commercial operations. This building has 5 floors with an area of $\pm 2023,44 \mathrm{~m}^{2}$. The roof of the building is planned using a concrete plate. The shear wall is planned to use the type of l frame wall from the ground floor to the 5th floor which aims to withstand the lateral force caused by the earthquake.

Calculation of structures in AnFen Office Center building using SNI 03-1726-2012 for earthquake resistant building count and SNI 03-2847-2002 for construction calculation. Lower structure planning includes pile foundation, pile cap, tie beam, while the top structure includes floor plate, column, beam, roof plate, ladder and shear wall. In the calculation of moments and reactions that work on this building using software SAP 2000 Version 17.2.0.

The result of design calculation of floor plate plate with thickness of $20 \mathrm{~cm}$ for ground floor plate and $12 \mathrm{~cm}$ for floor plate plate 1-5 up to roof plate. Design of beam design with dimensions B1= $450 \times 700, B 2=300 \times 550$. Design planning column with design K1 $=800 \times 800$. Design planning pile foundation diameter $60 \mathrm{~cm}$ at a depth of $12 \mathrm{~m}$.
\end{abstract}

Keywords: Planning, Structure Building, Structure Analysis Program (SAP) V.17.2.0, Earthquake. 


\section{Pendahuluan}

\subsection{Latar Belakang}

Jawa Tengah tepatnya di Kota Semarang dalam 2 tahun ini mengalami pertumbuhan ekonomi yang sangat pesat. Pertumbuhan ekonomi yang signifikan di Semarang menarik daya dukung investor untuk berinvestasi dan memunculkan sebuah ide membuat suatu gedung untuk persewaan perkantoran. Tujuan tempat penyewaan adalah menyediakan gedung

untuk disewakan ke perusahaan untuk dijadikan sebagai tempat peluang pekerjaan.

Dengan adanya pembangunan Office Centre AnFen tersebut maka diharapkan dapat menambah tempat sewa perkantoran bagi pengusaha yang membutuhkan tempat untuk membuka perkantoran baru maupun cabang didaerah Semarang kota.

\subsection{Lokasi Proyek dan Data Teknis}

Proyek pembangunan Office Centre AnFen ini secara geografis letak bangunannya dibatasi oleh:

1. Sebelah Utara : Gang Pringgading.

2. Sebelah Timur : Rumah Warga.

3. Sebelah Barat : Jalan Pringgading 3.

4. Sebelah Selatan : Jalan Pringgading.

Data teknis Proyek pembangunan Gedung

Fakultas Teknik Universitas Moren Semarang sebagai berikut :

1. Luas Lahan : $2.023,44 \mathrm{~m}^{2}$.

2. Luas Bangunan $: 1200 \mathrm{~m}^{2}$.

3. Jumlah Lantai : 5 Lantai.

Tabel 1.1 Elevasi dan Luasan Gedung

\begin{tabular}{|c|c|c|}
\hline Lantai & Elevasi $(\mathrm{m})$ & Luas $\left(\mathrm{m}^{2}\right)$ \\
\hline Ground floor & $\pm 0,00$ & 1.575 \\
\hline Lantai 1 & $+3,50$ & 1.575 \\
\hline Lantai 2 & $+7,00$ & 1.575 \\
\hline Lantai 3 & $+10,5$ & 1.575 \\
\hline Lantai 4 & $+14,0$ & 1.575 \\
\hline Lantai 5 & $+17,5$ & 1.575 \\
\hline
\end{tabular}

\subsection{Tujuan Perencanaan}

Tujuan yang hendak dicapai dari penyusunan tugas akhir ini yaitu:

1. Mengetahui tahapan dalam perencanaan struktur yang meliputi perhitungan dan gambar konstruksi untuk pembangunan office centre AnFen Semarang.

2. Menganalisis suatu perhitungan struktur untuk tercapainya keamanan dan keekonomian sebuah gedung.

3. Mengerti sebuah logika struktur dari konstruksi beton.

\section{Perencanaan Struktur}

2.1 Uraian Umum
Beberapa kriteria yang harus dipenuhi dalam perencanaan gedung bertingkat adalah:

\section{Perencanaan}

Suatu proses yang mencoba meletakkan

dasar tujuan dan sasaran termasuk menyiapkan segala sumber daya untuk mencapainya. Perencanaan memberikan pegangan bagi pelaksanaan mengenai alokasi sumber daya untuk melaksanakan kegiatan (Suharto, 1997). Inti dari perencanaan yaitu sebagai dasar untuk meletakan sasaran proyek seperti halnya dalam penjadwalan, anggaran dan mutu.

\section{Penjadwalan}

Maksud dari penjadwalan adalah agar

proyek selesai tepat waktu dengan biaya yang ekonomis maka setiap aktivitas harus dilaksanakan dengan membuat sistem penjadwalan yang tepat sesuai dengan berakhirnya kontrak proyek. dalam pengertian penjadwalan didalam proyek konstruksi merupakan cara untuk menentukan aktivitas dan urutan kerja dalam waktu tertentu (Callahan, 1992). Termasuk dalam penjadwalan tenaga kerja, material, peralatan, keuangan, dan waktu. Dengan adanya penjadwalan yang tepat maka beberapa macam kerugian dapat

diminimalkan seperti keterlambatan, pembengkakan biaya, dan perselisihan.

\section{Pengendalian}

Usaha untuk menganalisis kemungkinan

adanya penyimpangan antara pelaksanaan dan standar untuk mengambil tindakan dalam pembetulan yang sesuai dengan sasaran perencanaan, merancang sistem informasi, membandingkan pelaksanaan dengan standar secara efektif dan efisien dalam rangka mencapai sasaran (Suharto, 1997).

4. Metode Pengendalian biaya dan waktu Untuk mengetahui pengendalian biaya dan waktu dapat menggunakan 2 metode, yaitu:

a. Metode Varian

Cara mengidentifikasi varian pada 
pengeluaran biaya pelaksanaan terhadap biaya rencana dalam kurun waktu tertentu.

b. Metode Nilai Hasil

Membuat perkiraan atau proyeksi keadaan berdasarkan asumsi-asumsi tertentu dimana untuk menhetahui keadaan masa depan proyek dengan cara mengetahui performance proyek dari sisi biaya, penjadwalan, prediksi biaya setelah evaluasi untuk mengetahui untung atau rugi, dan prediksi waktu dalam menyelesaikan proyek setelah evaluasi pada suatu waktu untuk mengetahui cepat atau lambatnya dalam suatu pekerjaan proyek.

\subsection{Modifikasi Perencanaan Gedung}

Perencanaan Office Centre AnFen Semarang ini merupakan perencanaan hasil modikasi yang dilakukan pada bagian pelebaran jarak gedung. Modifikasi dilakukan pada luas yang semula $28 \mathrm{~m} \times$ $40 \mathrm{~m}$ menjadi $30 \mathrm{~m} \times 40 \mathrm{~m}$. Modifikasi juga dilakukan pada denah setiap lantainya seperti penambahan kantor dan kantin serta mengubah denah lantai 1 yang awalnya ada out door untuk smooking area dan menjadi full indoor sehingga yang mula kantornya berjumlah 5 kantor perlantai menjadi 6 kantor.

\subsection{Tinjauan Pustaka}

\subsubsection{Pembebanan}

Perencanaan pada proyek struktur gedung Office Centre Anfen direncanakan dengan kekuatannya terhadap pembebanan, sebagai berikut:

Kombinasi beban pada struktur beton (SNI 032847-2002):

$U=1,2 D+1,6 L \pm 1,0 E$

Keterangan:

$U$ adalah kekuatan menahan beban terfaktor, momen dan gaya $\left(\mathrm{kg} / \mathrm{m}^{2}\right)$.

$D$ adalah beban mati $\left(\mathrm{kg} / \mathrm{m}^{2}\right)$.

$L$ adalah beban hidup $\left(\mathrm{kg} / \mathrm{m}^{2}\right)$.

$E$ adalah beban gempa $\left(\mathrm{kg} / \mathrm{m}^{2}\right)($ SNI 03-1726-

2012).

\subsubsection{Pembebanan Gempa Menggunakan Analisa Statistik Ekivalen}

Gaya gempa diasumsikan sebagai gaya lateral horizontal yang bekerja pada setiap lantai gedung. Berdasarkan Perencanaan Ketahanan

Gempa Untuk Struktur Bangunan Gedung SNI 03-1726-2012 rumus yang digunakan sebagai berikut.

$$
\begin{aligned}
& \text { Keterangan: } \\
& F i \quad \text { = beban gempa pada lantai tingkat } \\
& \text { ke-i (ton) } \\
& V \quad=\text { beban geser dasar nominal (ton) } \\
& W i \quad \text { = berat lantai tingkat ke-i (ton) }
\end{aligned}
$$

$\mathrm{K}=$ eksposnen yang terkait dengan prioda struktur

$H i=$ ketinggian lantai tingkat ke-i (meter)

Sedangkan beban gempa dasar gedung yaitu beban horisontal lateral dihitung dengan persamaan:

$V=$

Keterangan:

$V \quad=$ beban geser dasar nominal (ton)

$W \quad=$ berat seismik efektif (ton)

Cs = koefisien respons seismik 
Pada bangunan gedung Office Centre AnFen Semarang yang menggunakan struktur rangka beton bertulang dengan kategori gedung penting maka $I=1,5$ dan $R=8$ (SNI 031726-2012).

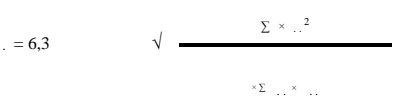

Keterangan:

$T=$ waktu getar alami (detik)

$\mathrm{Wi} \quad=$ berat lantai $\mathrm{ke}-\mathrm{i}(\mathrm{kg})$

Fi $x, y \quad=$ gaya gempa lantai ke-i $(\mathrm{kg})$

Waktu getar struktur dikontrol dengan cara T. Rayleigh dengan syarat selisih waktu getar $(T)$ dengan waktu getar hasil analisis vibrasi 3 dimensi, tidak boleh melebihi $20 \%$ dikarenakan, jika melebihi syarat ketentuan dari $20 \%$ maka akan terjadi kegagalan struktur yang membuat gedung mengalami kerusakan karena kurangnya kekakuan untuk menahan getaran gaya lateral horizontal.

2.3.3 Perhitungan Plat Lantai 1-5 dan atap Dalam perencanaan ini digunakan plat beton. Rumus yang digunakan dalam pengecekan hasil perhitungan penulangan plat lantai adalah sebagai berikut: (PBI, 1971)

$d y \quad-$

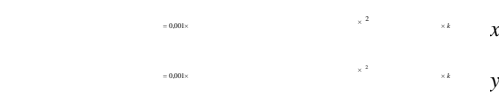

$M_{n} \quad=$

$M_{n} \quad \ldots$

$M_{n}$

$T_{S} \quad=C_{C}$

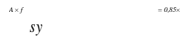

Kontrol pembatasan luas tulangan minimum tulangan plat lantai dapat menggunakan rumus sebagai berikut:

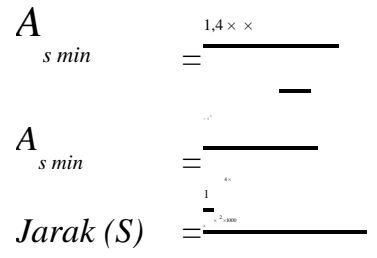

\subsubsection{Perhitungan Tangga}

Pada tugas akhir kali ini, momen maksimum yang diperoleh yang terjadi pada tangga diperoleh dari hasil output menggunakan 
program SAP 2000 Version 17.2.0 Build 1140 yang kemudian diolah dengan rumus sebagai berikut :

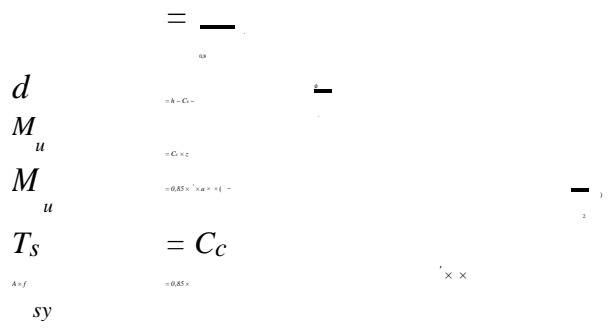

Kontrol pembatasan luas tulangan minimum tangga dapat menggunakan rumus sebagai berikut :

A

$\operatorname{Jarak}(S)=$

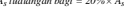

\subsubsection{Perhitungan Balok}

Menganalisis perhitungan struktur balok dengan satuan yang digunakan adalah A.S. Analisis desain balok (McCormac, 2004), sebagai berikut :

A. Desain penampang balok

Rumus untuk pengecekan hasil dari luas penampang dan tulangan tarik pada balok sebagai berikut :

$$
=1,2 \mathrm{D}+
$$

$w_{u} \quad 1,6 L$

$M_{u}=\square$

$=0,75$

$=0,85$ (untuk beton maksimal

$4000 \mathrm{psi})$

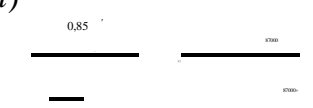

$=\underline{-}$, tidak boleh kurang dari

$+\quad-$

$=($ dimensi balok $)$

B. Desain tulangan tarik balok

Luas minimum tulangan yang diperlukan untuk menahan gaya tarik balok dihitung dengan rumus : $A$

C. Desain tulangan tekan balok

Rumus untuk mengecek hasil dari luas penampang tulangan tekan yang dibutuhkan oleh balok sebagai berikut :
$C \quad=0,85$

Rumus lanjutan apabila tulangan tekan meleleh :

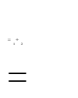

D. Desain tutangan geser balok

Rumus untuk mengecek hasil dari luas penampang dan jarak tulangan geser

balok setagai berikut : $V_{c}=2 \sqrt{ }{ }^{\prime} b_{n} d$
Sengkang diperlukan jika, $V_{u}={ }_{2} V_{c}$

Rumus jika diperlukan sengkang,

$s \quad=/ V_{s}$

$\left.V_{s} \quad V_{c}\right)$

\subsubsection{Perhitungan Kolom}

Menganalisis perhitungan struktur kolom dengan satuan yang digunakan adalah A.S. Analisis desain kolom (McCormac, 2004), sebagai berikut :

A. Desain dimensi kolom

$=\left(V_{u} \quad\right.$ Rumus untuk mengecek hasil dari dimensi kolom

sebagai berikut :

$=1,2 D+1,6 L$

(Persamaan ACI 10-2)

$A g \quad=$ Luas penampang kolom

$A_{g}=-$ )

Asumsi yang digunakan,

$$
=0,02 \mathrm{Ag}
$$

B. Desain tulangan kolom

Pada kolom yang hanya dibebani aksial, kebutuhan tulangan dihitung dengan rumus pengecekan sebagai berikut :

$$
=1,2 D+1,6 L
$$

$=$ Luas tulangan kolom

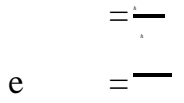

- = Dengan interpolasi grafik maka didapatkan 
$=$

C. Desain tulangan geser kolom Rumus yang akan digunakan untuk pengeceka hasil dari luas penampang dan jarak tulangan geser kolom adalah sebagai berikut :

V

Sengkang diperlukan jika,

Rumus jika diperlukan sengkang,

$$
s \quad=
$$

Jarak maksimum untuk menentukan tulangan geser minimum,

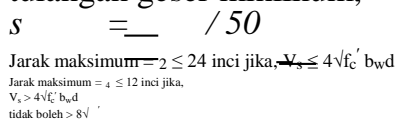

\subsubsection{Perhitungan Pondasi Tiang}

Pancang Rumus-rumus yang digunakan antara lain :

1. Perhitungan daya dukung tiang pancang berdasarkan hasil sondir (Nottingham, 1975).

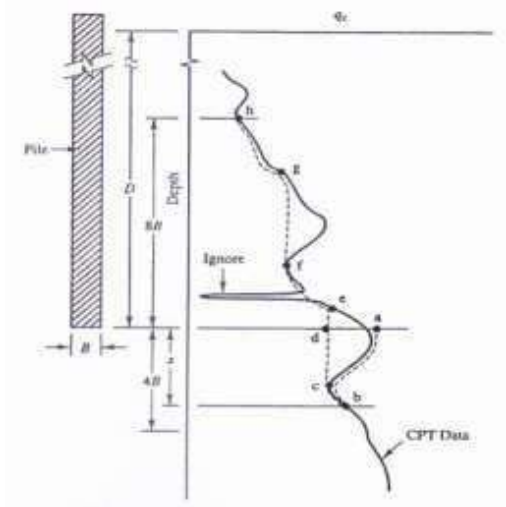

Gambar 2.1 Perhitungan Data Dukung Ujung Sumber : Buku Manual Pondasi Tiang Edisi 3 (2005)

Untuk mendapatkan daya dukung selimut tiang maka digunakan rumus sebagai berikut:
Kapasitas daya dukung ultimit ditentukan dengan persamaan sebagai berikut :

Keterangan :

$\mathrm{Qu} \quad=$ kapasitas daya dukung aksial ultimit tiang pancang (ton)

Qp = kapasitas tahanan di ujung tiang (ton)

Qs = kapasitas tahanan kulit (ton)

Besarnya faktor aman yang telah banyak digunakan untuk perancangan pondasi tiang pancang sebagai berikut :

Keterangan :

$\mathrm{Q}_{\mathrm{a}} \quad=$ kapasitas tiang ijin (ton)

$\mathrm{Qu}=$ kapasitas daya dukung aksial ultimit tiang pancang (ton)

2. Perhitungan daya dukung tiang pancang berdasarkan Bearing capacity and settlement of pile foundations (Meyerhof, 1976), sebagai berikut:

Daya dukung ujung tiang dihitung dengan menggunakan rumus :

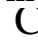

C

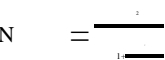

qp

Qp

Daya dukung selimut tiang pancang dihitung menggunakan rumus :

$\mathrm{f} \quad=$

Qs

Daya dukung tiang pancang :

\subsubsection{Perhitungan Pile Cap}

Perhitungan analisis pilecap menggunkan satuan SI. (Pamungkas dan Erny, 2013), sebagai berikut :

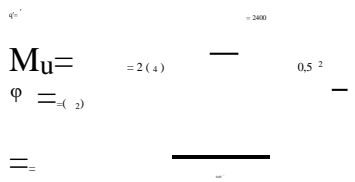

\subsubsection{Perhitungan Tie Beam}


Perhitungan analisis tie beam menggunkan satuan SI. (Pamungkas dan Erny, 2013), sebagai berikut :

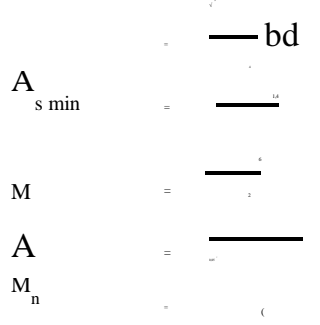

\subsubsection{Shear Wall}

Shear wall merupakan dinding beton dengan tulangan atau pra-tegang yang mampu menahan beban dan tegangan, khususnya tegangan horisontal akibat beban gempa (McCormac, 2004). Fungsi utama dari dinding geser adalah menahan beban lateral gaya gempa dan angin. Dengan adanya dinding geser yang kaku pada bangunan, sebagian besar beban gempa akan terserap oleh dinding geser tersebut (McCormac, 2004). Perhitungan gaya-gaya yang terjadi pada struktur meliputi berat sendiri / beban mati ( $\left.\mathrm{W}_{\mathrm{bs}}\right)$, beban hidup (WL), dan beban gempa. Berat sendiri terdiri dari berat sendiri plat $\left(\mathrm{Wp}_{\mathrm{i}}\right)$, berat sendiri balok $\left(\mathrm{Wb}_{\mathrm{i}}\right)$, berat sendiri kolom $\left(\mathrm{Wk}_{\mathrm{i}}\right)$, berat sendiri dinding geser $\left(\mathrm{Wd}_{\mathrm{i}}\right)$. Dengan menggunakan SAP 2000 Version 17.2.0 Build untuk mendapatkan hasil gaya geser yang bekerja pada dinding, yang dibebani oleh beban hidup, beban mati dan gempa. (McCormac, 2004)

\subsection{Asumsi-asumsi}

Asumsi-asumsi yang digunakan dalam perencanaan gedung ini adalah:

1. Struktur utama dibuat dari konstruksi beton bertulang sedangkan atap menggunakan plat beton.

2. Beban mati yang digunakan: (PPIUG 1983 Tabel 2.1)
a. Beton bertulang
$=2400 \mathrm{~kg} / \mathrm{m}^{3}$
b. Pasir
$=1800 \mathrm{~kg} / \mathrm{m}^{3}$
c. Spesi dengan tebal $1 \mathrm{~cm}=21 \quad \mathrm{~kg} / \mathrm{m}^{2}$
d. Pasangan bata merah tebal setengah batu
$\begin{array}{lll} & =250 & \mathrm{~kg} / \mathrm{m}^{2} \\ \text { e. Plafon dan penggantung } & =18 & \mathrm{~kg} / \mathrm{m}^{2} \\ \text { f. Keramik } & =24 & \mathrm{~kg} / \mathrm{m}^{2}\end{array}$

3. Beban hidup yang digunakan: (PPIUG 1983

Tabel 3.1)

a. Gudang, janitor, lavatory, selasar

$$
=250 \mathrm{~kg} / \mathrm{m}^{2}
$$

b. Tangga dan bordes $\quad=300 \mathrm{~kg} / \mathrm{m}^{2}$

c. Lantai ruang, kantin, kantor

$$
\begin{aligned}
& =400 \mathrm{~kg} / \mathrm{m}^{2} \\
\text { d. Atap } & =100 \mathrm{~kg} / \mathrm{m}^{2}
\end{aligned}
$$

Pada suatu bangunan bertingkat banyak, kecil kemungkinan tiap lantai akan dibebani secara penuh oleh beban hidup. Demikian juga kecil kemungkinannya suatu struktur bangunan menahan beban maksimum akibat pengaruh angin atau gempa yang bekerja secara bersamaan (McCormac, 2004). Pedomanpedoman pembebanan mengijinkan untuk melakukan reduksi terhadap beban hidup yang dipakai. Reduksi adalah suatu faktor yang dipakai untuk mengkalikan kuat nominal untuk mendapatkan kuat rencana. Koefisien reduksi beban hidup untuk gempa sebesar 0,5 dan untuk portal dan balok induk sebesar 0,9. Reduksi beban dapat dilakukan dengan mengalihkan beban hidup dengan suatu koefisien reduksi yang nilainya tergantung pada penggunaan bangunan.

4. Faktor-faktor reduksi kekuatan beton (SNI03-2847-2002):
a. Lentur
b. Geser $(u V)$ dan torsi $(T) \quad: 0,75$
c. Aksial tarik dengan lentur $\quad: 0,80$
d. Aksial tekan dengan lentur $\quad: 0,65$

5. Plat lantai beton yang digunakan yaitu setebal $12 \mathrm{~cm}$ dan plat atap yang digunakan yaitu setebal $12 \mathrm{~cm}$.

6. Balok

Tipe balok induk yang direncanakan adalah $450 \mathrm{~mm} / 700 \mathrm{~mm}$. Sedangkan tipe balok anak yang direncanakan adalah $300 \mathrm{~mm} / 550$ $\mathrm{mm}$.

7. Kolom

Tipe kolom yang direncanakan yaitu kolom persegi dengan ukuran dimensi $800 \mathrm{~mm} \times 800 \mathrm{~mm}$. Ukuran ini masih dapat berubah bila hasil dari analisis perhitungan SAP 2000 Version 17.2.0 Build tidak memenuhi.

8. Beban merata $(q)$ yang berasal dari beban plat ekuivalen maupun berat sendiri balok dan plat akan diterima oleh balok anak dan atau balok induk. Sistem pembebanan didasarkan pada anggapan bahwa balok anak dan balok induk merupakan konstruksi yang menerima beban secara bersamaan. Beban tersebut akan didistribusikan ke kolom oleh balok yang kemudian diteruskan ke pondasi. 
9. Tebal dinding direncanakan pasangan batu bata setengah batu dengan tebal $15 \mathrm{~cm}$ termasuk plesteran dan acian.

10.Perhitungan mekanika menggunakan aplikasi software komputer yaitu SAP 2000 Version 17.2.0 Build 1140.

11. Data mekanika tanah

Data tanah yang digunakan adalah data penyelidikan tanah proyek pembanguan gedung bertingkat di Jl. Pringgading No 24 Semarang.

12.Pondasi gedung direncanakan menggunakan pondasi tiang pancang.

\section{Metodologi penelitian}

\subsection{Tinjauan Umum}

Dalam perencanaan khususnya untuk struktur Gedung Office Centre AnFen Semarang terdapat beberapa langkah yang perlu dilakukan. Berikut ini adalah langkah-langkahnya yaitu:

1. Survei Lokasi

2. Design Arsitektural

3. Pembuatan Rencana Kerja dan Syarat Syarat (RKS)

4. Analisis dan perencanaan struktur

5. Gambar struktur

6. Perhitungan RAB

7. Pembuatan time schedule

\section{Analisa dan Pembahasan}

\subsection{Perencanaan Pembebanan Plat Lantai}

Analisa perhitungan pelat lantai dan pelat atap

Plat beton bertulang yang direncanakan pada sturktur menggunakan mutu beton dengan

tulangan utama menggunakan

Dalam perencanaan struktur plat lantai struktur gedung office centre Semarang ini dibagi dalam tiga bagian, yaitu :

1. Pembebanan lantai Ground Floor

2. Pembebanan lantai 1-5

3. Pembebanan plat atap

Langkah-langkah perencanaan plat lantai :

1. Menentukan batas luasan plat, tumpuan, dan panjang bentang.

2. Menentukan tebal plat lantai dan melakukan checking terhadap lendutan yang diijinkan.

3. Menghitung beban yang dipikul pada plat lantai, yang terdiri dari beban mati (DL) dan beban hidup (LL), lalu dihitung menggunakan kombinasi.

\subsection{Perhitungan Tangga}

Pada setiap lantai di gedung terdapat tangga yang memiliki dimensi tipikal. Posisi tangga yaitu:

1. Tebal Plat 1

$\mathrm{m}$

2. Panjang Tangga

3. Tinggi Tangga

$\mathrm{m}$

4. Lebar anak tangga

$\mathrm{m}$

5. Panjang bordes

6. Tinggi bordes

7. Optrede/tanjakan

8. Antrede/injakan

9. Jumlah anak tangga (beda tinggi/optrede) -1
$-1$
10. Beban hidup
11. Berat jenis beton
12. Sudut $(\alpha)$

\subsection{Perhitungan Gaya Gempa}

Berdasarkan SNI 03-1726-2012 analisis beban gempa pada struktur gedung direncanakan dengan tujuan Menghindari terjadinya korban jiwa manusia oleh runtuhnya gedung akibat gempa yang kuat. Membatasi kerusakan gedung akibat gempa ringan sampai sedang, sehingga masih dapat diperbaiki. Mengurangi ketidaknyamanan penghunian bagi penghuni gedung ketika terjadi gempa ringan sampai sedang.

Tabel 4.1 Distribusi gaya geser horisontal total akibat gempa arah $\mathrm{x}$ dan $\mathrm{y}$

\begin{tabular}{|c|c|c|}
\hline Lantai & Fi x $(\mathrm{kg})$ & Fi y $(\mathrm{kg})$ \\
\hline ground & 0 & 0 \\
\hline 1 & $\mathbf{2 0 2 3 , 8}$ & $\mathbf{1 8 2 7}$ \\
\hline 2 & $\mathbf{3 5 2 0}$ & $\mathbf{3 1 7 9}$ \\
\hline 3 & $\mathbf{4 9 3 6}$ & $\mathbf{4 4 6 0}$ \\
\hline 4 & $\mathbf{6 2 8 9}$ & $\mathbf{5 6 8 5}$ \\
\hline 5 & $\mathbf{7 6 0 9}$ & $\mathbf{6 8 7 9}$ \\
\hline atap & $\mathbf{5 6 2 1}$ & $\mathbf{5 0 8 3}$ \\
\hline
\end{tabular}

\subsection{Perencanaan Balok dan Kolom}

Perencanaan balok dan kolom dilakukan dengan melakukan asumsi terlebih dahulu, setelah asumsi yang ada dilakukan per-modelan dengan menggunakan SAP v17. Hasil reaksi dan gaya oleh SAP v17 akan dilakukan perhitungan penulangan meng-gunakan rumus. 
Tabel 4.2 Hasil Perhitungan Balok

\begin{tabular}{|c|c|c|c|}
\hline $\begin{array}{c}\text { Tipe } \\
\text { Balok }\end{array}$ & $\begin{array}{c}\text { Dimensi } \\
\text { Balok }\end{array}$ & $\begin{array}{c}\text { Tulangan } \\
\text { Tumpuan }\end{array}$ & $\begin{array}{c}\text { Tulangan } \\
\text { Lapangan }\end{array}$ \\
\hline B1 & $450 \times 700$ & 6 D 22 & 6 D 22 \\
\hline B2 & $350 \times 500$ & 3 D 16 & 3 D 16 \\
\hline
\end{tabular}

Tabel 4.3 Hasil Perhitungan Kolom

\begin{tabular}{|c|c|c|c|}
\hline $\begin{array}{c}\text { Tipe } \\
\text { Kolom }\end{array}$ & $\begin{array}{c}\text { Dimensi } \\
\text { Kolom }\end{array}$ & $\begin{array}{c}\text { Tulangan } \\
\text { Utama }\end{array}$ & $\begin{array}{c}\text { Tulangan } \\
\text { Sengkang }\end{array}$ \\
\hline K1 & $800 \times 800$ & 22 D 22 & $10-150$ \\
\hline
\end{tabular}

\subsection{Perencanaan Pondasi}

Pondasi yang direncanakan adalah pondasi tiang pancang. Perhitungan daya dukung pondasi tiang pancang untuk perencanaan struktur gedung Office Centre AnFen berdasarkan CPT (Cone Penetration Test) dan SPT (Standard Penetration Test) dari laboratorium mekanika tanah Unika Soegijapranata.

Ukuran pondasi tiang pancang diameter $60 \mathrm{~cm}$ dengan kedalaman pondasi $12 \mathrm{~m}$ dari permukaan tanah.

\subsection{Perencanaan Pilecap}

Desain pilecap yang digunakan ada lima macam, yaitu Terdapat 2 jenis pilecap yang digunakan yaitu pilecap dengan 9 tiang pancang (PC1), dan 8 tiang (PC2).

\subsection{Perencanaan Tie Beam}

\begin{tabular}{|c|c|c|c|}
\hline $\begin{array}{c}\text { Tipe Tie } \\
\text { Beam }\end{array}$ & Dimensi & $\begin{array}{c}\text { Tulangan } \\
\text { Utama }\end{array}$ & $\begin{array}{c}\text { Tulangan } \\
\text { Sengkang }\end{array}$ \\
\hline TB1 & $400 \times 600$ & 8 D 16 & D10 -250 \\
\hline
\end{tabular}

\section{RAB dan Kurva-S}

Dalam analisis biaya konstruksi ini dijelaskan mengenai perhitungan harga satuan pekerjaan. Harga satuan pekerjaan ini berdasarkan HSPK tahun terbaru yang bersumber dari SNI 2012. Pada analisa biaya konstruksi ini meliputi data harga satuan barang, upah, alat, maupun material. Dari harga satuan pekerjaan dilakukan perhi-tungan volume tiap-tiap pekerjaan, khu-susnya struktur. Sehingga diperoleh biaya yang dibutuhkan dalam pembangunan struk-tur gedung. Total biaya struktur adalah Rp. 27.696.420.000,00,- dengan waktu pekerjaan selama sembilan bulan yaitu dari bulan Juni 2018 hingga bulan Februari 2019.

\subsection{Kesimpulan}

Dari hasil perhitungan Perencanaan Struktur Gedung Office Centre AnFen Semarang diperoleh :

1. Struktur atap menggunakan plat beton bertulang dengan tebal $12 \mathrm{~cm}$.

2. Plat lantai dengan tebal $12 \mathrm{~cm}$ untuk lantai $1-5$.

3. Plat lantai Ground Floor dengan tebal 20 $\mathrm{cm}$.

4. Tangga memiliki tebal plat $12 \mathrm{~cm}$, dan memiliki jumlah 22 anak tangga.

5. Bordes tebal $12 \mathrm{~cm}$ menggunakan beton (K$350)$.

6. Desain struktur portal utama adalah sebagai berikut :

a. Balok $(\mathrm{K}-350) f^{\prime}{ }_{c}=29 \mathrm{MPa}$

1) $\mathrm{B} 1=(45 \times 70) \mathrm{cm}$

2) $\mathrm{B} 2=(30 \times 55) \mathrm{cm}$

b. Kolom $(\mathrm{K}-350) f^{\prime}{ }_{c}=29 \mathrm{MPa}$

1) $\mathrm{K} 1=(80 \times 80) \mathrm{cm}$

c. Tie Beam $(\mathrm{K}-350) f^{\prime}{ }_{c}=29 \mathrm{MPa}$

1) $\mathrm{TB} 1=(40 \times 60) \mathrm{cm}$

d. Pondasi(K-350)

Menggunakan pondasi tiang pancang dengan bentuk lingkaran dengan diameter $50 \mathrm{~cm}$ dengan kedalaman 12 meter.

7. Perhitungan struktur ini menggunakan SAP 2000 Version 17.2.0 Build 1140.

8. Hasil perhitungan rencana anggaran biaya struktur gedung ini + profit dan PPN sebesar Rp 27,696,420,000.-.

\subsection{Saran}

Saran yang bisa digunakan untuk menyempurnakan tugas akhir perencanaan ini seperti :

1. Beban-beban asumsi yang akan membebani struktur harus diperhatikan secara teliti untuk mengurangi kesalahan,

2. Asumsi dimensi struktur (balok, kolom, pelat) terlebih dahulu dicek menggunakan program apakah sudah memenuhi persyaratan keamanan sebelum dilakukan analisis perhitungan tulangan, 
3. Cermat dan teliti dalam memasukan input program SAP supaya tidak terjadi kesalahan dalam perhitungan reaksi yang dihasilkan.

\section{DAFTAR PUSTAKA}

Badan Pusat Statistik (BPS) (2017), Kota Semarang.

Callahan, M., (1992). "Contruction Project

Scheduling”, Mc Graw Hill, New York.

GEC FT Unpar., (2005), Manual Pondasi Tiang Edisi 3 , Bandung.

Https://www.google.co.id/maps/@6.9832193,110.4 $2834,190 \mathrm{~m} /$ data $=! 3 \mathrm{~m} 1$ !1. (Diunduh pada 6 juli 2017 pukul 13.20 WIB)

Https://finance.detik.com/berita-ekonomibisnis/3530708/semarang-penyangga-utamapertumbuhan-ekonomi-jateng (diunduh pada 26 Oktober 2017 pukul 13.20 wib).

Https://semarangkota.bps.go.id/website/pdf_publik asi/Kecamatan-Semarang- Tengah-Dalam-Angka2017.pdf (diunduh pada 26 Oktober 2017).

McCormac, J.C., (2004), "Desain Beton Bertulang Edisi Kelima Jilid 1”, Erlangga,Jakarta.

McCormac, J.C., (2004), "Desain Beton Bertulang Edisi Kelima Jilid 2”, Erlangga,Jakarta.

Meyerhof, G. G., (1976). Bearing capacity and settlement of pile foundations. J Geotech Eng Div 102:195-228.

Nottingham, L. C., (1975). Use of quasi- static friction cone penetrometer data to predict load capacity of displacement piles. Ph.D Thesis, University of Florida. Pamungkas, A, dan Erny, H., (2013). Desain Pondasi Tahan Gempa, Andi, Yogyakarta.

Peraturan Beton Indonesia 1971 (PBI 71)., Dirjend Cipta Karya DPU 1971.

SNI 03-1726-2012, (2012), Tata Cara Perencanaan Ketahanan Gempa Untuk Struktur Bangunan Gedung. Bandung.

SNI 03-2847-2002, (2002), Tata Cara Perhitungan Struktur Beton untuk Bangunan Gedung. Bandung.
Soeharto, I., (1997). "Manajemen Proyek", Erlangga, Jakarta.

Wangsadinata, W., (1971). Peraturan Beton

Bertulang Indonesia. Bandung. 